\title{
Faktor-faktor yang Memengaruhi Keberhasilan Usaha Mustahik pada Program Zakat Produktif LAZ An-Nuur
}

\section{Factors Affecting The Success of Mustahik Enterprises in The Productive Zakat Program of LAZ An-Nuur}

\author{
Hardinata Muhammad ${ }^{1}$, Deni Lubis ${ }^{2}$, Dedi Budiman Hakim ${ }^{3}$ \\ ${ }^{1}$ Departemen Ilmu Ekonomi Syariah, Institut Pertanian Bogor 16680, email: dinatamasta@gmail.com \\ ${ }^{2}$ Departemen Ilmu Ekonomi Syariah, Institut Pertanian Bogor 16680, email: denilubis@gmail.com \\ ${ }^{3}$ Departemen Ilmu Ekonomi, Institut Pertanian Bogor 16680, email: dbhakim@ipb.ac.id
}

\begin{abstract}
The high level of poverty in Indonesia becomes one of the problems that have not been successfully overcame by the government. Bogor Regency is the district with the poorest population in West Java Province in 2016. Many programs have been undertaken to overcome these problems by government of Bogor Regency. One of them is by optimizing the utilization of productive zakat conducted by Lembaga Amil Zakat (LAZ). LAZ An-Nuur established mustahik empowerment program by providing productive zakat in the form of financing for entrepreneurship. This study aims to analyze the factors that influence the success of a mustahik's business in utilizing the productive zakat given by LAZ An-Nuur. The method used in this research is descriptive analysis and logistic regression analysis. Respondents in this study consisted of 48 beneficiaries of productive zakat funds. The results show that the factors that proved to influence the success of LAZ An-Nuur mustahik's business are the age, length of business, business profits, and the frequency of financing.
\end{abstract}

Keywords: logistic regression, mustahik, productive zakat, successful business

\begin{abstract}
Abstrak. Tingginya tingkat kemiskinan di Indonesia menjadi salah satu permasalahan yang belum berhasil diatasi oleh pemerintah. Kabupaten Bogor menjadi kabupaten yang memiliki penduduk miskin paling banyak di Provinsi Jawa Barat pada tahun 2016. Berbagai program telah dilakukan untuk mengatasi permasalahan tersebut oleh Pemerintah Kabupaten Bogor. Salah satunya dengan mengoptimalkan pemanfaatan zakat produktif yang dilakukan Lembaga Amil Zakat (LAZ). LAZ AnNuur membentuk program pemberdayaan mustahik dengan memberikan zakat produktif dalam bentuk pembiayaan untuk berwirausaha. Penelitian ini bertujuan untuk menganalisis faktor-faktor yang memengaruhi keberhasilan usaha mustahik dalam memanfaatkan zakat produktif yang diberikan oleh LAZ An-Nuur. Metode yang digunakan dalam penelitian ini adalah analisis deskriptif dan analisis regresi logistik. Responden dalam penelitian ini terdiri dari 48 penerima manfaat dana zakat produktif. Hasil penelitian menunjukan bahwa faktor-faktor yang terbukti memengaruhi keberhasilan usaha mustahik LAZ An-Nuur adalah usia, lama usaha, laba usaha, dan frekuensi pembiayaan.
\end{abstract}

Kata kunci: keberhasilan usaha, mustahik, regresi logistik, zakat produktif

\section{PENDAHULUAN}

\section{Latar Belakang}

Tingginya tingkat pra sejahtera menjadi salah satu permasalahan di Indonesia yang belum berhasil diatasi oleh pemerintah. Data BPS (2017) menunjukkan bahwa pada tahun 2017 jumlah penduduk pra sejahtera di Indonesia berjumlah 27771 juta orang atau sebesar $10.46 \%$ dari total populasi, diikuti dengan tingginya Indeks Rasio Gini di Indonesia, yaitu sebesar 0.393.

Provinsi Jawa Barat memiliki penduduk pra sejahtera terbanyak urutan ke-3 setelah Provinsi Jawa Timur dan Provinsi Jawa Tengah. Data BPS (2017) menunjukan jumlah penduduk pra sejahtera di Provinsi Jawa Barat pada tahun 2017 berjumlah 4168 juta orang. Pada tahun 2016 Kabupaten Bogor menjadi kabupaten yang memiliki penduduk pra sejahtera paling banyak di Provinsi Jawa Barat, berjumlah 490800 orang (BPS, 2017). Data tersebut dapat dilihat pada Tabel 1, yang menunjukan 
jumlah penduduk dan penduduk pra sejahtera Kabupaten Bogor mengalami peningkatan pada tahun 2015 hingga tahun 2016. Jumlah penduduk Kabupaten Bogor pada tahun 2015 hingga tahun 2016 meningkat sebesar $2.338 \%$, sedangkan jumlah penduduk pra sejahtera meningkat sebesar $0.759 \%$. Hal ini menunjukan bahwa pada tahun 2016 jumlah penduduk pra sejahtera Kabupaten Bogor sebesar $8.784 \%$ dari total penduduk.

Tabel 1 Lima besar jumlah penduduk dan penduduk pra sejahtera di kabupaten pada Provinsi Jawa Barat tahun 2015-2016

\begin{tabular}{lcccc}
\hline \multirow{2}{*}{ Kabupaten } & \multicolumn{2}{c}{ Jumlah Penduduk (ribu) } & \multicolumn{2}{c}{ Jumlah Penduduk Pra Sejahtera (ribu) } \\
\cline { 2 - 5 } & 2015 & 2016 & 2015 & 2016 \\
\hline Bogor & $\mathbf{5 4 5 9 . 7}$ & $\mathbf{5 5 8 7 . 4}$ & $\mathbf{4 8 7 . 1}$ & $\mathbf{4 9 0 . 8}$ \\
Cianjur & 2243.9 & 2251.0 & 273.9 & 261.3 \\
Bandung & 3534.1 & 3596.6 & 281.0 & 272.6 \\
Garut & 2548.7 & 2569.5 & 325.7 & 298.5 \\
Cirebon & 2126.2 & 2143.0 & 313.2 & 288.4 \\
\hline
\end{tabular}

Sumber: BPS (2017)

Pada sisi lain, garis kemiskinan Kabupaten Bogor dari tahun 2011 hingga tahun 2016 mengalami peningkatan. Data tersebut dapat dilihat pada Gambar 1, yang menunjukkan penurunan hanya terjadi pada tahun 2013, berjumlah Rp6 609 atau sebesar 2.55\% dari tahun 2012. Pada tahun 2013 hingga tahun 2016 mengalami peningkatan yang cukup signifikan, berjumlah Rp64 888 atau sebesar 25.69\% (BPS, 2017).

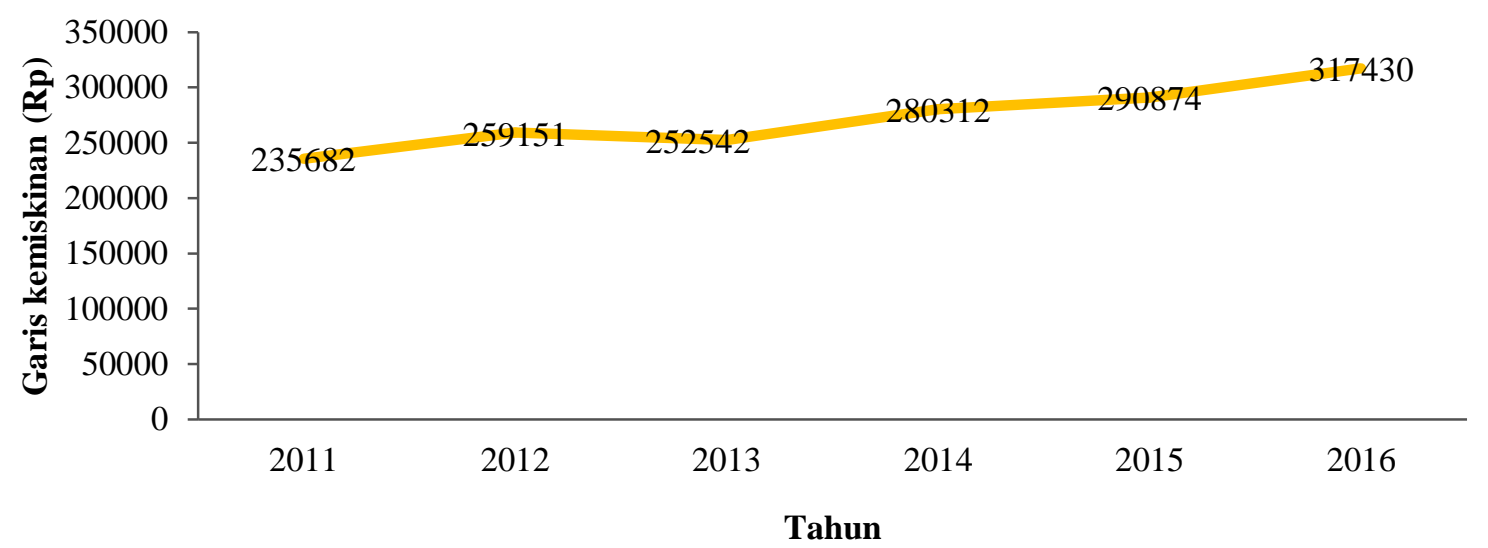

Sumber: BPS (2017), diolah

Gambar 1 Garis kemiskinan Kabupaten Bogor tahun 2011-2016

Kecamatan Dramaga merupakan salah satu kecamatan di Kabupaten Bogor. Kecamatan Dramaga terdiri dari 10 desa. Jumlah keluarga pra sejahtera Kecamatan Dramaga mengalami peningkatan pada tahun 2016 hingga tahun 2017. Pada tahun 2016 tercatat sebanyak 3191 keluarga dan meningkat pada tahun 2017 menjadi 3523 keluarga. Data tersebut dapat dilihat pada Gambar 2.

Berdasarkan Gambar 2, dapat diketahui bahwa pada tahun 2017 desa yang memiliki jumlah keluarga pra sejahtera paling banyak terdapat di Desa Petir, berjumlah 830 keluarga dan desa yang memiliki jumlah keluarga pra sejahtera paling sedikit terdapat di Desa Babakan, berjumlah 79 keluarga. Keluarga pra sejahtera di Desa Sinarsari pada tahun 2016 tercatat sebanyak 267 keluarga dan mengalami peningkatan pada tahun 2017 sebanyak 22 keluarga atau sebesar $8.23 \%$ menjadi 289 keluarga.

Pandangan Islam terhadap masalah kemiskinan merupakan suatu keniscayaan dalam kehidupan (sunnatullah fil hayah). Islam tidak pernah berbicara tentang upaya untuk menghilangkan kemiskinan, tetapi berbicara bagaimana mereduksi dan meminimalisasi tingkat kemiskinan yang terjadi (Beik \& 2 
Arsyianti, 2015). Salah satu upaya untuk meminimalisasi tingkat kemiskinan tersebut adalah dengan mengoptimalkan pendayagunaan zakat, infak, dan sedekah (ZIS) yang terhimpun pada tahun 2015 mencapai Rp3 700 miliar dan memiliki potensi zakat nasional pada tahun 2015 mencapai Rp286 triliun (Puskas BAZNAS, 2017).



Sumber: Kantor Kecamatan Dramaga (2017), diolah

Gambar 2 Keluarga pra sejahtera Kecamatan Dramaga, tahun 2016-2017

Zakat merupakan rukun Islam yang ke-3. Maka dari itu, wajib hukumnya membayar zakat bagi setiap muslim yang telah memenuhi kriteria tertentu. Seorang muslim dianggap telah keluar dari agama dan diancam oleh Allah SWT dengan azab yang pedih, jika menolak untuk menunaikan rukun Islam khususnya membayar zakat. Hal tersebut sesuai dengan firman Allah pada surat Fushilat ayat 7.

Seorang muslim yang menunaikan zakat disebut sebagai muzaki, yang berarti orang yang menyucikan harta benda dan jiwanya. Muzaki dianjurkan menyalurkan zakatnya kepada organisasi pengelola zakat (amil), untuk disalurkan kepada orang yang berhak menerimanya (mustahik). Mustahik terbagi menjadi 8 golongan dan golongan yang paling diprioritaskan adalah fakir dan miskin. Hal tersebut dikarenakan fakir dan miskin disebutkan lebih awal dalam firman Allah pada surat At-Taubah ayat 60 .

Zakat yang dihimpun oleh amil secara umum disalurkan dalam dua bentuk, yaitu secara konsumtif (zakat konsumtif) dan produktif (zakat produktif). Hal ini sesuai dengan Undang-Undang Zakat Nomor 23 Tahun 2011 tentang Pengelolaan Zakat. Zakat produktif bertujuan untuk memberdayakan dana zakat untuk kegiatan yang dapat menghasilkan atau bermanfaat dalam jangka panjang. Zakat produktif yang diberikan oleh amil kepada mustahik, pada penelitian ini berbentuk pembiayaan menggunakan akad pinjaman dana tanpa imbalan dengan kewajiban mengembalikan pokok pinjaman secara sekaligus atau cicilan dalam jangka waktu tertentu (qardhul hasan).

\section{Perumusan Masalah}

BPS (2017) mencatat sebanyak 8260 orang atau sebesar 96.85\% dari total penduduk Desa Sinarsari Kecamatan Dramaga pada tahun 2016 memeluk agama Islam. Hal ini menunjukkan bahwa mayoritas masyarakat Desa Sinarsari Kecamatan Dramaga adalah muslim. Sebagaimana diketahui, salah satu kewajiban seorang muslim adalah mengeluarkan zakat. Hal tersebut, berdasarkan firman Allah dalam surat At-Taubah ayat 103. Untuk memudahkan dalam pengumpulan dan penyaluran zakat, maka dibentuklah organisasi pengelola zakat (OPZ), yaitu LAZ An-Nuur secara swadaya oleh masyarakat Desa Sinarsari Kecamatan Dramaga.

Salah satu fungsi zakat di bidang ekonomi adalah menjadi instrumen pemerataan pendapat yang berujung pada pengentasan kemiskinan (Beik, 2009). Untuk mewujudkan fungsi tersebut, LAZ AnNuur Desa Sinarsari meluncurkan program zakat produktif berupa pembiayaan untuk unit usaha 
menggunakan akad qardhul hasan. Diharapkan melalui program ini, keluarga pra sejahtera dapat mengakses modal untuk membuka atau mengembangkan usaha yang pada akhirnya dapat mengentaskan keluarga pra sejahtera di Desa Sinarsari. Program ini telah berlangsung sejak tahun 2002.

Pada kenyataannya, tidak semua mustahik yang mendapat pembiayaan berhasil dalam berwirausaha dan jumlah keluarga pra sejahtera Desa Sinarsari tidak semakin menurun, justru menunjukkan hal yang sebaliknya. Dari tahun 2016 hingga tahun 2017 jumlah keluarga pra sejahtera Desa Sinarsari meningkat walaupun tidak dalam jumlah yang signifikan. Menurut laporan Kecamatan Dramaga, pada awal tahun 2017, keluarga pra sejahtera Desa Sinarsari meningkat sebanyak 22 keluarga atau setara dengan $8.24 \%$ dari total keluarga pra sejahtera tahun 2016. Keadaan ini menunjukkan ketidaksesuaian teori dengan realita yang terjadi. Berdasarkan uraian yang telah dipaparkan, maka rumusan masalah dengan beberapa pertanyaan dalam penelitian ini adalah sebagai berikut:

1 Bagaimana karakteristik demografi sosial-ekonomi mustahik LAZ An-Nuur Desa Sinarsari?

2 Fakor-faktor apa saja yang memengaruhi keberhasilan usaha mustahik LAZ An-Nuur Desa Sinarsari?

\section{Ruang Lingkup}

Ruang lingkup pada penelitian ini terbatas pada faktor-faktor yang memengaruhi keberhasilan usaha mustahik pada program zakat produktif LAZ An-Nuur. Ruang lingkup keberhasilan usaha dalam penelitian ini adalah peluang keberhasilan usaha yang dimiliki oleh seseorang untuk berhasil atau tidak berhasil dalam mendayagunakan zakat produktif. Variabel dependen dalam penelitian ini, yaitu keberhasilan usaha terdiri dari dua kategori: Berhasil, dengan ciri-ciri usahanya aktif, mustahik aktif melakukan angsuran pembiayaan, dan omzet usaha yang diperoleh mampu menutupi modal awal usaha dalam jangka waktu dua bulan, dan Tidak Berhasil, dengan ciri-ciri usahanya tidak aktif, mustahik tidak aktif melakukan angsuran pembiayaan, dan omzet usaha yang diperoleh tidak mampu menutupi modal awal usaha dalam jangka waktu dua bulan.

\section{TINJAUAN PUSTAKA}

Menurut Rozalinda (2015), zakat produktif dapat digunakan oleh kelompok miskin, selain untuk membangun usaha dapat digunakan sebagai tambahan modal usaha, sehingga usaha yang dijalankan dapat berjalan lancar dan dapat menambah penghasilan. Dalam jangka panjang, peningkatan ekonomi umat melalui zakat produktif dapat meringankan beban negara dalam pengentasan kemiskinan dan pengangguran. Berdasarkan penelitian yang mengkaji dampak zakat produktif terhadap kemiskinan yang dilakukan oleh Beik (2009), Tsani (2010), Hartoyo dan Purnamasari (2010), dan Anriani (2010) menyimpulkan bahwa zakat terbukti mampu mengurangi jumlah dan persentase keluarga miskin, serta mengurangi kedalaman dan keparahan kemiskinan.

Widiyanto et al. (2011) meneliti efektivitas pembiayaan qardhul hasan yang dilakukan oleh Baitul Mal Wat Tamwil (BMT) untuk mengentaskan kemiskinan. Metode yang digunakan, yaitu uji $\mathrm{t}$ dua sampel berpasangan dan analisis regresi logistik. Hasil uji t membuktikan bahwa pembiayaan qardhul hasan berpengaruh positif dan signifikan terhadap omzet dan keuntungan usaha mikro. Faktor yang terbukti berpengaruh signifikan terhadap performa usaha mikro setelah mendapatkan pembiayaan qardhul hasan adalah usia pelaku usaha mikro dengan pengaruh negatif.

Murniati dan Beik (2013) meneliti mengenai pengaruh zakat terhadap indeks pembangunan manusia dan tingkat kemiskinan mustahik pada kasus pendayagunaan BAZNAS Kota Bogor. Penelitian ini bertujuan untuk menganalisis program pendayagunaan zakat yang dilakukan BAZNAS Kota Bogor serta dampaknya terhadap kehidupan mustahik, baik ditinjau dari perubahan pada pendapatan mustahik pasca distribusi zakat, maupun dari sisi nilai IPM dan tingkat kemiskinan mustahik. Metode analisis yang digunakan, yaitu uji t-statistik, estimasi nilai IPM tingkat individu mustahik, dan indikator kemiskinan. Hasil uji t-statistik menunjukkan bahwa pemberian zakat kepada mustahik 
memberikan pengaruh nyata pada tingkat pendapatannya. Begitu juga dengan nilai IPM mustahik yang mengalami peningkatan dari angka 47 sebelum distribusi zakat menjadi 49 setelah distribusi zakat. Hasil studi menunjukkan adanya penurunan pada tingkat kemiskinan mustahik berdasarkan pada empat indikator kemiskinan yang digunakan, yaitu headcount ratio index $(\mathrm{H})$, poverty gap index (P1), income gap indeks (I), dan sen indeks of poverty (P2).

Mursalina dan Syarifah (2015) meneliti dampak zakat produktif terhadap perkembangan usaha mikro mustahik pada usaha mikro binaan BAZNAS di Kabupaten Bogor. Metode yang digunakan adalah analisis regresi linier berganda. Hasil penelitian ini menunjukkan bahwa lama usaha, lama pendidikan, dan dummy usaha yang berpengaruh positif terhadap penghasilan, sedangkan dummy jenis kelamin berpengaruh negatif terhadap aset. Variabel jumlah pembiayaan, lama usaha, perkembangan penghasilan, dan perkembangan modal berpengaruh positif terhadap keuntungan usaha, sedangkan aset berpengaruh negatif.

Ali et al. (2016) meneliti mengenai perbandingan zakat produktif dan zakat konsumtif dalam meningkatkan kesejahteraan mustahik. Metode yang digunakan adalah analisis deskriptif, model CIBEST, dan analisis regresi logistik. Hasil penelitian ini menunjukan bahwa zakat produktif lebih mampu mengurangi kemiskinan dibanding zakat konsumtif. Faktor-faktor yang berpengaruh positif dan signifikan terhadap rumah tangga mustahik untuk menuju kuadran sejahtera dengan adanya zakat produktif adalah pendapatan rumah tangga mustahik dan pekerjaan kepala rumah tangga, sedangkan pada zakat konsumtif faktor-faktor yang berpengaruh terhadap hal tersebut adalah pendidikan kepala rumah tangga dan pendapatan rumah tangga mustahik.

Tunas (2014) meneliti mengenai analisis pengaruh pembiayaan syariah terhadap perkembangan Usaha, Mikro, Kecil, dan Menengah (UMKM) di Kota Depok. Metode yang digunakan adalah analisis regresi logistik dan Ordinary Least Square (OLS). Hasil penelitian ini menunjukan bahwa faktor-faktor yang memengaruhi akses UMKM terhadap pembiayaan mikro syariah adalah lama usaha dan omzet usaha berpengaruh positif, sedangkan total aset dan jumlah tabungan berpengaruh negatif. Hasil dari OLS, yaitu jumlah pembiayaan mikro syariah berpengaruh positif terhadap perkembangan usaha UMKM yang dapat dilihat dari perkembangan omzet dengan peningkatan omzet usaha sebesar Rp115 juta atau 30.31\%. Faktor-faktor yang memengaruhi nilai perkembangan omzet adalah frekuensi pembiayaan, lama usaha, dan jumlah pembiayaan.

Haile (2015) meneliti faktor-faktor yang menentukan pengembalian pinjaman pada lembaga microfinance Harari. Penelitian ini dilakukan di daerah Harari, Euthopia. Teknik penentuan sampel pada penelitian ini menggunakan multistage sampling. Metode yang digunakan dalam penelitian ini, yaitu analisis deskriptif dan analisis regresi logistik. Hasil penelitian menunjukan terdapat lima variabel yang memiliki pengaruh positif, yaitu jumlah keluarga, lama usaha, periode pelunasan, pelatihan, dan pendapatan lain di luar bisnis.

Gina dan Effendi (2015) melakukan penelitian mengenai program pembiayaan Lembaga Keuangan Mikro Syariah (LKMS) dalam peningkatan kesejahteraan pelaku usaha mikro (Studi kasus: BMT Baitul Karim Bekasi). Tujuan penelitian ini, yaitu menganalisis pengaruh program pembiayaan dalam peningkatan pendapatan dan kesejahteraan pelaku usaha mikro. Metode yang digunakan adalah Ordinary Least Square (OLS) dan analisis regresi logistik. Faktor-faktor yang secara positif signifikan memengaruhi peningkatan pendapatan adalah pembiayaan yang diambil responden, jumlah anggota keluarga yang berpenghasilan, pendidikan, dan variabel etika dan moral. Faktor-faktor yang secara positif dan signifikan memengaruhi peningkatan kesejahteraan, yaitu lamanya menjadi anggota, pengeluaran makan, pendapatan rata-rata, dan pembiayaan yang diambil responden. 


\section{METODE}

\section{Waktu dan Lokasi Penelitian}

Penelitian ini dilakukan pada mustahik yang mendapatkan dana zakat produktif dalam bentuk pembiayaan menggunakan akad qardhul hasan di LAZ An-Nuur Desa Sinarsari, Kecamatan Dramaga, Kabupaten Bogor Jawa Barat. Penentuan lokasi penelitian ini dilakukan secara sengaja (purposive) dengan pertimbangan meningkatnya jumlah keluarga pra sejahtera di Desa Sinarsari, dana ZIS yang terhimpun di LAZ An-Nuur setiap tahun, dan disertai dengan meningkatnya jumlah mustahik. Penelitian ini dilaksanakan dari bulan September hingga November 2017.

\section{Jenis dan Sumber Data}

Jenis dan sumber data dibagi menjadi dua kategori, yaitu data primer dan data sekunder. Data primer dikumpulkan dari hasil pengisian kuesioner yang dilakukan dengan wawancara secara langsung kepada pengurus LAZ An-Nuur dan mustahik penerima dana zakat produktif LAZ An-Nuur. Selanjutnya, data sekunder digunakan untuk melengkapi data primer yang sudah ada dan diperoleh dari berbagai literatur, instansi pemerintah, dan penelitian terdahulu yang dijadikan sebagai bahan rujukan yang berhubungan dengan pembiayaan dan zakat produktif.

\section{Sampel Penelitian}

Penentuan sampel dilakukan dengan menggunakan teknik pengambilan sampel non acak dengan purposive sampling. Penentuan banyaknya sampel yang digunakan dalam penelitian ini menggunakan metode Slovin. Jumlah populasi penelitian ini berjumlah 92 orang, maka jumlah sampel yang digunakan berjumlah 48 orang yang telah dihitung menggunakan metode Slovin dengan perhitungan sampelnya $d=10 \%$.

\section{Metode Analisis Data}

Metode analisis yang digunakan dalam penelitian ini adalah metode analisis deskriptif dan analisis regresi logistik. Metode analisis deskriptif pada penelitian ini menggunakan pendekatan kuantitatif dan kualitatif. Pendekatan kuantitatif dan kualitatif dilakukan dengan pencarian data-data melalui pengisian kuesioner dan wawancara secara langsung kepada mustahik untuk mengklasifikasikan karakteristik mustahik. Metode analisis regresi logistik pada penelitian ini digunakan untuk menentukan faktor-faktor yang memengaruhi keberhasilan usaha mustahik pada program zakat produktif LAZ An-Nuur.

\section{Analisis Deskriptif}

Metode deskriptif bertujuan untuk mendeskripsikan dan mempermudah penafsiran yang disajikan dalam bentuk tabel maupun grafik. Metode ini digunakan untuk mengkaji gambaran umum LAZ AnNuur dari segi sejarah lembaga, skema pembiayaan, serta program penyaluran ZIS, dan mengkaji karakteristik responden, karakteristik responden terhadap usaha yang dijalankan, karakter responden terhadap pembiayaan, status pendapatan usaha, alasan responden melakukan pembiayaan, dan saran responden terhadap LAZ An-Nuur. Metode ini juga digunakan untuk menginterpretasikan hasil yang diperoleh dari analisis kuantitatif, sehingga dapat memberikan gambaran yang jelas mengenai faktorfaktor yang memengaruhi keberhasilan usaha mustahik.

\section{Analisis Regresi Logistik}

Regresi logistik dalam penelitian ini digunakan untuk mengetahui faktor-faktor yang memengaruhi keberhasilan usaha mustahik pada program zakat produktif LAZ An-Nuur. Model logit yang digunakan adalah sebagai berikut:

$$
U_{i}=\operatorname{Ln}\left[\frac{P i}{1-P i}\right]=\beta_{0}+\beta_{1} X_{i 1}+\beta_{2} X_{i 2}+\beta_{3} X_{i 3}+\beta_{4} X_{i 4}+\beta_{5} X_{i 5}+\beta_{6} D_{i 1}+\beta_{7} D_{i 2}+\beta_{8} D_{i 3}+e_{i}
$$


Keterangan:

$U_{i} \quad=$ Mustahik berhasil dalam mendayagunakan zakat produktif

( $1=$ usaha aktif, aktif mengangsur pembiayaan, perolehan omzet usaha mampu menutupi modal usaha dalam jangka waktu dua bulan dan $0=$ usaha tidak aktif, tidak aktif mengangsur pembiayaan, perolehan omzet usaha tidak mampu menutupi modal usaha dalam jangka waktu dua bulan)

$\beta_{0} \quad=$ Konstanta atau intersep model regresi

$\beta_{1} \quad=$ Koefisien variabel ke-i $(\mathrm{i}=1 \ldots 8)$

$X_{1} \quad=$ Usia (tahun)

$X_{2} \quad=$ Laba Usaha $(1=<\mathrm{Rp} 750000,2=\mathrm{Rp} 750000 \leq \mathrm{x}<\mathrm{Rp} 1500000,3=\mathrm{Rp}$

$1500000 \leq \mathrm{x}<\mathrm{Rp} 2200000$, dan $4=\geq \operatorname{Rp} 2200000)$

$X_{3} \quad=$ Lama Usaha $(1=<1$ tahun, $2=1-3$ tahun, $3=4-6$ tahun, $4=\geq 7$ tahun $)$

$X_{4}=$ Frekuensi Pembiayaan ( $1=1$ kali, $2=2$ kali, $3=3$ kali, $4=\geq 4$ kali)

$X_{5} \quad=$ Tingkat Pendidikan $(1=\mathrm{SD}, 2=\mathrm{SMP}, 3=\mathrm{SMA}, 4=$ Diploma $)$

$D_{1} \quad=$ Dummy Jenis Usaha 1 (1= Dagang dan 0= Lainnya)

$D_{2} \quad=$ Dummy Jenis Usaha $2(1=$ Jasa dan $0=$ Lainnya $)$

$D_{3} \quad=$ Dummy Jenis Usaha 3 ( $1=$ Pertanian dan $0=$ Lainnya $)$

e $\quad=$ Galat atau error

\section{HASIL DAN PEMBAHASAN}

\section{Gambaran Umum}

LAZ An-Nuur merupakan lembaga zakat yang belum terdaftar sebagai lembaga zakat yang resmi. Hal ini dikarenakan LAZ An-Nuur belum memiliki izin resmi pembentukan LAZ yang diberikan oleh Kepala Kantor Wilayah Kementerian Agama provinsi. Oleh karena itu, lembaga ini hanya mendapatkan sumber dana ZIS dari kalangan masyarakat saja dan tidak mendapatkan dana ZIS dari pemerintah atau lembaga-lembaga zakat lainnya. Sumber dana ZIS yang diterima oleh LAZ An-Nuur bersumber dari kalangan masyarakat yang disalurkan kepada mustahik melalui dua program, yaitu zakat konsumtif dan zakat produktif.

Pada program zakat produktif, LAZ An-Nuur menyalurkannya pada program pemberdayaan masyarakat pra sejahtera Desa Sinarsari dengan memberikan pembiayaan sebagai modal untuk menciptakan usaha atau tambahan modal usaha menggunakan akad qardhul hasan. Skema penyaluran dana ZIS LAZ An-Nuur dapat dilihat pada Gambar 3.

Berdasarkan Gambar 3, bagi pengusaha yang berhasil diharapkan segera mengangsur pembiayaan dari hasil keuntungan usahanya. Namun, bagi pengusaha yang tidak berhasil tidak wajib melakukan pengembalian pembiayaan. Jika mustahik sudah melunasi pembiayaannya, mustahik dapat mendapatkan pembiayaan kembali dengan perolehan dana pembiayaan yang lebih besar dibandingkan dana pembiayaan sebelumnya.

Penghimpunan dana ZIS di LAZ An-Nuur diperoleh dari masyarakat dalam berbagai bentuk, diantaranya zakat mal, zakat fitrah, sumbangan infak dan sedekah. Selain itu, dalam penyaluran dana zakat, LAZ An-Nuur menyalurkannya pada dua program, yaitu zakat konsumtif dan zakat produktif. Jumlah penghimpunan dan penyalurannya dapat dilihat pada Gambar 4.

Berdasarkan Gambar 4, dapat diketahui jumlah penyaluran zakat konsumtif LAZ An-Nuur paling besar terjadi pada tahun 2015, hal tersebut dikarenakan sebagian besar dana ZIS digunakan untuk merenovasi bangunan Masjid An-Nuur. Jumlah penghimpunan ZIS paling banyak terjadi pada tahun 2017 disertai dengan jumlah penyaluran zakat produktif. Frekuensi penyaluran zakat produktif kepada mustahik oleh LAZ An-Nuur dapat dilihat pada Tabel 2. 


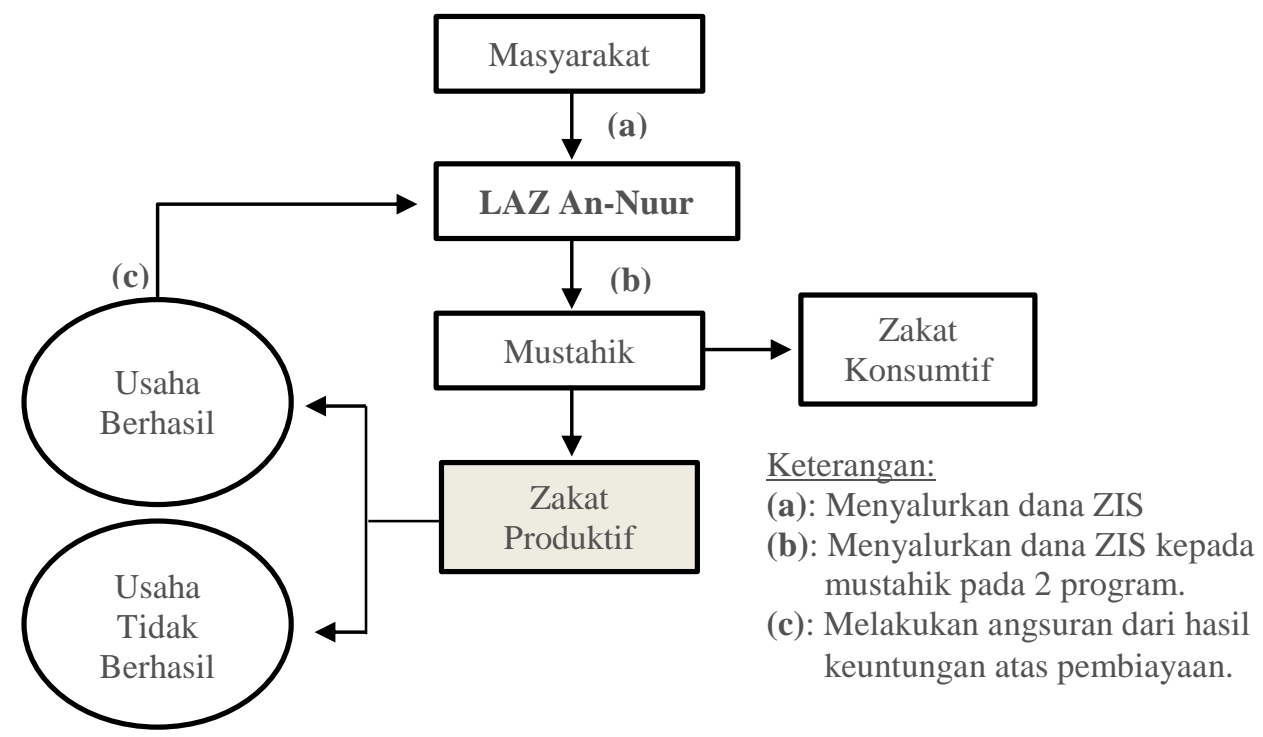

Sumber: LAZ An-Nuur (2017), diolah

Gambar 3 Skema penyaluran dana ZIS LAZ An-Nuur

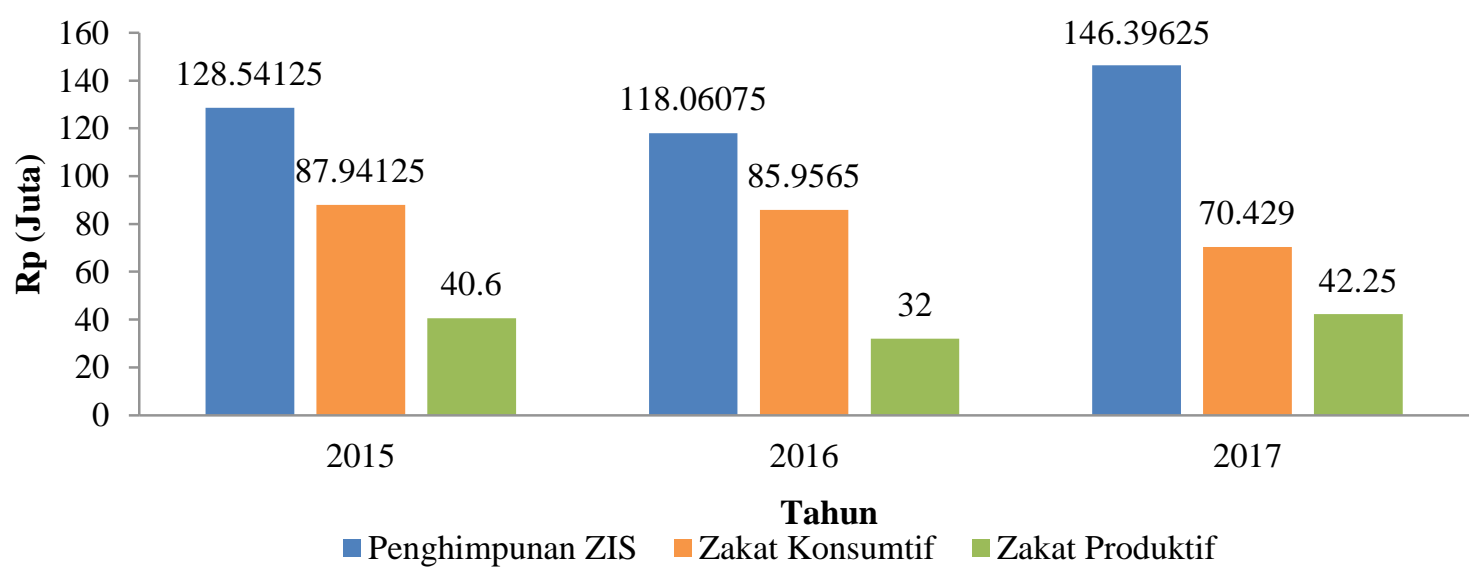

Gambar 4 Jumlah penghimpunan dan penyaluran ZIS LAZ An-Nuur tahun 2015-2017

Tabel 2 menunjukan bahwa frekuensi penyaluran zakat produktif paling banyak terjadi pada tahun 2015 berjumlah 59 kali. Frekuensi penyaluran zakat produktif paling sedikit terjadi pada tahun 2016 berjumlah 38 kali. Hal tersebut dikarenakan jumlah mustahik yang mengajukan pembiayaan pada tahun 2016 tidak sebanyak pada tahun 2015.

Tabel 2 Frekuensi penyaluran zakat produktif LAZ An-Nuur tahun 2015-2017

\begin{tabular}{cccc}
\hline Tahun & 2015 & 2016 & 2017 \\
\hline $\begin{array}{c}\text { Frekuensi penyaluran zakat } \\
\text { produktif (kali) }\end{array}$ & 59 & 38 & 50 \\
\hline $\begin{array}{c}\text { Sumber: LAZ An-Nuur (2017), diolah } \\
\text { (20) }\end{array}$ & & &
\end{tabular}

\section{Karakteristik Responden, Usaha, dan Pembiayaan}

Responden pada penelitian ini berjumlah 48 orang. Data karakteristik pada penelitian ini disajikan menjadi tiga jenis, di antaranya karakteristik responden, karakteristik responden dari segi usaha, dan karakteristik responden dari segi pembiayaannya. Adapun data tersebut dapat dilihat pada tabel berikut. 
Tabel 3 Karakteristik responden

\begin{tabular}{|c|c|c|c|c|}
\hline \multirow{2}{*}{$\begin{array}{l}\text { Karakteristik } \\
\text { Responden }\end{array}$} & \multicolumn{2}{|c|}{ Usaha Berhasil } & \multicolumn{2}{|c|}{ Usaha Tidak Berhasil } \\
\hline & Total & Persentase (\%) & Total & Persentase (\%) \\
\hline \multicolumn{5}{|l|}{ Jenis kelamin } \\
\hline Laki-laki & 14 & 29.17 & 5 & 10.42 \\
\hline Perempuan & 25 & 52.08 & 4 & 8.333 \\
\hline Total & 39 & 81.25 & 9 & 18.75 \\
\hline \multicolumn{5}{|l|}{ Usia (tahun) } \\
\hline $21-30$ & 6 & 12.50 & 0 & 0 \\
\hline $31-40$ & 13 & 27.08 & 4 & 8.333 \\
\hline $41-50$ & 13 & 27.08 & 2 & 4.167 \\
\hline $51-60$ & 7 & 14.58 & 0 & 0 \\
\hline$>60$ & 0 & 0 & 3 & 6.250 \\
\hline Total & 39 & 81.25 & 9 & 18.75 \\
\hline \multicolumn{5}{|c|}{ Tingkat pendidikan } \\
\hline SD & 22 & 45.83 & 2 & 4.167 \\
\hline SMP & 8 & 16.67 & 3 & 6.250 \\
\hline SMA & 8 & 16.67 & 4 & 8.333 \\
\hline Diploma & 1 & 2.083 & 0 & 0 \\
\hline Total & 39 & 81.25 & 9 & 18.75 \\
\hline \multicolumn{5}{|l|}{ Status pernikahan } \\
\hline Menikah & 35 & 72.91 & 8 & 16.66 \\
\hline Belum Menikah & 0 & 0 & 0 & 0 \\
\hline Janda/Duda & 4 & 8.333 & 1 & 2.083 \\
\hline Total & 39 & 81.25 & 9 & 18.75 \\
\hline \multicolumn{5}{|l|}{ Status keluarga } \\
\hline Kepala Keluarga & 12 & 25 & 6 & 12.5 \\
\hline Anggota Keluarga & 27 & 56.25 & 3 & 6.25 \\
\hline Total & 39 & 81.25 & 9 & 18.75 \\
\hline \multicolumn{5}{|c|}{ Jumlah tanggungan (orang) } \\
\hline $0-1$ & 5 & 10.41 & 1 & 2.083 \\
\hline $2-3$ & 25 & 52.08 & 8 & 16.66 \\
\hline$>3$ & 9 & 18.75 & 0 & 0 \\
\hline Total & 39 & 81.25 & 9 & 18.75 \\
\hline
\end{tabular}

Berdasarkan Tabel 4, dapat diketahui bahwa mayoritas karakteristik responden terhadap usaha yang berhasil berjenis usaha dagang, sudah melakukan usaha selama $\geq 7$ tahun, memperoleh laba usaha dalam sebulan sebesar Rp1 $500000 \leq \mathrm{x}<\mathrm{Rp2} 200$ 000, dan jumlah operasional usaha dalam seminggu selama 4-7 hari.

Tabel 4 Karakteristik usaha responden

\begin{tabular}{lcccc}
\hline \multirow{2}{*}{ Karakteristik Responden } & \multicolumn{2}{c}{ Usaha Berhasil } & \multicolumn{2}{c}{ Usaha Tidak Berhasil } \\
\cline { 2 - 5 } Jenis usaha & Total & Persentase (\%) & Total & Persentase (\%) \\
Dagang & 27 & 56.25 & 4 & 8.333 \\
Pertanian/ternak & 1 & 2.083 & 3 & 6.250 \\
Jasa & 5 & 10.42 & 0 & 0 \\
Produksi rumah tangga & 6 & 12.50 & 2 & 4.167 \\
\hline Total & 39 & 81.25 & 9 & 18.75 \\
\hline Lama usaha (tahun) & 3 & & & \\
$\leq 1$ & 10 & 20.83 & 3 & 10.42 \\
$1-3$ & 11 & 22.92 & 0 & 6.250 \\
$4-6$ & & &
\end{tabular}




\begin{tabular}{lcccc}
$\geq 7$ & 15 & 31.25 & 1 & 2.083 \\
\hline Total & 39 & 81.25 & 9 & 18.75 \\
\hline Laba usaha (Rp) & & & & \\
$<750000$ & 2 & 4.167 & 6 & 12.50 \\
$750000 \leq \mathrm{x}<1500000$ & 6 & 12.50 & 1 & 2.083 \\
$1500000 \leq \mathrm{x}<2200000$ & 16 & 33.33 & 2 & 4.167 \\
$\geq 2200000$ & 15 & 31.25 & 0 & 0 \\
\hline Total & 39 & 81.25 & 9 & 18.75 \\
\hline Jumlah operasional usaha (hari) & & & \\
0 & 0 & 0 & 6 & 12.50 \\
$1-3$ & 4 & 8.333 & 0 & 0 \\
$4-7$ & 35 & 72.91 & 3 & 6.250 \\
\hline Total & 39 & 81.25 & 9 & 18.75 \\
\hline Sumber: Data primer, diolah & & & &
\end{tabular}

Berdasarkan Tabel 5, dapat diketahui bahwa mayoritas karakteristik responden terhadap pembiayaan yang berhasil sudah lama melakukan pembiayaan selama $<1$ tahun, banyaknya melakukan pembiayaan sebanyak 1 kali, memperoleh pembiayaan sebesar $<750000$, dan sumber pembiayaan hanya bersumber dari LAZ An-Nuur.

Tabel 5 Karakteristik responden terhadap pembiayaan

\begin{tabular}{lcccc}
\hline \multirow{2}{*}{ Karakteristik Responden } & \multicolumn{3}{c}{ Usaha Berhasil } & \multicolumn{2}{c}{ Usaha Tidak Berhasil } \\
\cline { 2 - 5 } Lama pembiayaan (tahun) & Total & Persentase (\%) & Total & Persentase (\%) \\
$<1$ & 14 & 29.17 & 0 & 0 \\
$1-2$ & 6 & 12.50 & 8 & 16.67 \\
$\geq 3$ & 19 & 35.58 & 1 & 2.083 \\
\hline Total & 39 & 81.25 & 9 & 18.75 \\
\hline Frekuensi pembiayaan (kali) & & & & \\
1 & 18 & 37.50 & 7 & 14.58 \\
2 & 12 & 25.00 & 2 & 4.167 \\
3 & 7 & 14.58 & 0 & 0 \\
$\geq 4$ & 2 & 4.167 & 0 & 0 \\
\hline Total & 39 & 81.25 & 9 & 18.75 \\
\hline Perolehan pembiayaan (Rp) & & & & \\
$<750000$ & 13 & 27.08 & 3 & 6.250 \\
\hline $750000 \leq x<1500000$ & 12 & 25.00 & 4 & 8.333 \\
$1500000 \leq x<2400000$ & 11 & 22.92 & 2 & 4.167 \\
$\geq 2400000$ & 3 & 6.250 & 0 & 0 \\
\hline Total & 39 & 81.75 & 9 & 18.75 \\
\hline Sumber pembiayaan lain & & & & \\
Ada & 11 & 22.92 & 0 & 0 \\
Tidak ada & 28 & 58.33 & 9 & 18.75 \\
\hline Total & 39 & 81.25 & 9 & 18.75 \\
\hline Sumber: Data primer, diolah & & & &
\end{tabular}

\section{Hasil Uji Regresi Logistik}

Hasil uji menunjukkan $R$-Squared 0.845 , artinya model dapat menjelaskan faktor-faktor yang memengaruhi keberhasilan usaha mustahik sebesar $84.5 \%$, sedangkan sisanya dapat dijelaskan di luar model. Hasil uji Chi-Square Hosmer dan Lemeshow Test menunjukkan nilai Chi-Square sebesar 0.359 dengan $P$-Value $1.00>0.05$ sehingga model logit secara keseluruhan dapat digunakan dalam penelitian ini. Adapun data hasil uji selengkapnya dapat dilihat pada Tabel 6. 
Berdasarkan Tabel 6, dapat diketahui variabel usia berpengaruh signifikan negatif pada taraf nyata 5\% dan memiliki odds ratio sebesar 0.585. Dapat disimpulkan bahwa semakin tua usia responden, maka akan menurunkan peluang keberhasilan usaha sebesar 0.585 kali. Hal tersebut diduga semakin tinggi usia responden, maka responden tersebut semakin tidak produktif. Hasil yang sama juga ditemukan pada penelitian yang dilakukan Rachman (2014) dan Karimah (2015), bahwa usia berpengaruh negatif terhadap pendapatan usaha.

Tabel 6 Hasil uji regresi logistik

\begin{tabular}{lccr}
\hline Variabel & Parameter & -Value & Odds Ratio \\
\hline Usia & $\mathbf{0 . 5 3 5}$ & $\mathbf{0 . 0 4 0}^{* *}$ & $\mathbf{0 . 5 8 5}$ \\
Lama Usaha & $\mathbf{2 . 9 1 3}$ & $\mathbf{0 . 0 8 9}^{*}$ & $\mathbf{1 8 . 4 1 0}$ \\
Laba Usaha & $\mathbf{4 . 1 9 4}$ & $\mathbf{0 . 0 6 8}^{*}$ & $\mathbf{6 6 . 3 1 0}$ \\
Frekuensi Pembiayaan & $\mathbf{2 . 3 4 2}$ & $\mathbf{0 . 0 9 9}^{*}$ & $\mathbf{0 . 0 9 6}$ \\
Tingkat Pendidikan & -2.122 & 0.137 & 0.120 \\
Dummy Jenis Usaha 1 & 4.964 & 0.353 & 143.100 \\
Dummy Jenis Usaha 2 & 1.226 & 0.670 & 3.407 \\
Dummy Jenis Usaha 3 & 5.875 & 0.999 & 356.100 \\
\hline
\end{tabular}

Sumer: Data primer, diolah

Keterangan: * Signifikan pada taraf $10 \%$

** Signifikan pada taraf 5\%

Tabel 7 Usia mustahik LAZ An-Nuur

\begin{tabular}{ccccc}
\hline Usia Mustahik (tahun) & $\begin{array}{c}\text { Usaha } \\
\text { Berhasil }\end{array}$ & $\begin{array}{c}\text { Usaha Tidak } \\
\text { Berhasil }\end{array}$ & Total & Persentase (\%) \\
\hline $21-30$ & 6 & 0 & 6 & 12.5 \\
$31-40$ & 13 & 4 & 17 & 35.4 \\
$41-50$ & 13 & 2 & 15 & 31.2 \\
$51-60$ & 7 & 0 & 7 & 14.6 \\
$>60$ & 0 & 3 & 3 & 6.25 \\
\hline
\end{tabular}

Sumber: Data primer, diolah

Berdasarkan Tabel 7, mayoritas responden yang berhasil menginjak usia yang lebih muda, yaitu berkisar antara 31-50 tahun. Responden dengan usia paling tua, yaitu berusia $>60$ tahun berjumlah tiga orang dan usahanya tidak berhasil semua. Berdasarkan pengamatan di lapang, hal tersebut terjadi karena selain usianya menginjak usia tidak produktif, diduga jenis usaha yang ditekuni responden tersebut memiliki peluang keberhasilan yang kecil. Hal ini disebabkan responden tidak melakukan perencanaan usaha yang matang sebelum melakukan usaha dan modalnya sudah habis digunakan.

Variabel lama usaha berpengaruh signifikan positif pada taraf nyata $10 \%$ dan memiliki odds ratio sebesar 18.41. Dapat disimpulkan bahwa semakin lama responden melakukan usaha, maka akan meningkatkan peluang keberhasilan usahanya sebesar 18.41 kali. Hal tersebut sesuai dengan penelitian yang dilakukan oleh Karimah (2015) dan Tunas (2014) bahwa lama usaha berpengaruh positif terhadap perkembangan laba usaha. Semakin lama usaha yang ditekuni pelaku usaha, maka akan semakin banyak pengalaman yang didapatkan oleh pelaku usaha, baik dari segi pengetahuan maupun keterampilan dalam menjalankan usahanya, serta semakin lama usaha berdiri, maka kondisi usaha tersebut akan relatif lebih stabil jika dibandingkan dengan usaha yang baru berdiri.

Variabel laba usaha berpengaruh signifikan positif pada taraf nyata $10 \%$ dan memiliki odds ratio sebesar 66.31. Dapat disimpulkan bahwa semakin meningkat laba usaha yang diperoleh mustahik, maka akan meningkatkan peluang keberhasilan usaha sebesar 66.31 kali. Berdasarkan pengamatan di lapang, responden yang memperoleh laba usaha lebih banyak diduga dapat mengembangkan usahanya dengan baik dan lebih cepat melakukan pengembalian pembiayaan. Responden dapat melakukan pembiayaan kembali jika sudah melunasi pembiayaan dengan perolehan pembiayaan yang lebih besar dibandingkan pembiayaan sebelumnya, sehingga modal usahanya dapat menjadi bertambah. Hasil 
yang sama juga ditemukan oleh Anggraeni et al. (2013) bahwa laba usaha berpengaruh positif terhadap akses UMKM terhadap pembiayaan.

Variabel frekuensi pembiayaan siginifikan negatif pada taraf nyata $10 \%$ dan memiliki odds ratio sebesar 0.096. Dapat disimpulkan bahwa semakin banyak responden melakukan pembiayaan maka akan menurunkan peluang keberhasilan usaha sebesar 0.096 kali. Hasil yang sama juga ditemukan oleh Rahmi (2012) bahwa frekuensi pembiayaan berpengaruh negatif terhadap pembiayaan koperasi pada sektor agribisnis.

Berdasarkan data pada Tabel 8, dapat diketahui proporsi terbesar dimiliki oleh responden dengan frekuensi pembiayaan sebanyak satu kali sebesar $52.1 \%$ atau berjumlah 25 orang. Frekuensi pembiayaan dengan proporsi terkecil dimiliki oleh responden dengan frekuensi pembiayaan sebanyak $\geq 4$ kali sebesar $4.1 \%$ atau berjumlah dua orang. Dapat disimpulkan bahwa, semakin banyak responden melakukan pembiayaan, maka semakin sedikit jumlah respondennya. Kondisi ini dikarenakan banyaknya masyarakat yang baru mengetahui adanya wadah bagi yang membutuhkan pembiayaan yang diberikan oleh LAZ An-Nuur dan responden yang melakukan pembiayaan $\geq 4$ kali sudah lebih lama melakukan pembiayaan dengan LAZ An-Nuur, serta sudah melakukan wirausaha dengan waktu yang cukup lama dibandingkan dengan yang melakukan pembiayaan hanya satu kali. Pada sisi lain, LAZ An-Nuur juga berfokus untuk dapat menjangkau anggota baru sebanyakbanyaknya dengan tujuan agar dapat meminimalisasi tingkat kemiskinan di Kecamatan Dramaga khususnya di Desa Sinarsari.

Tabel 8 Frekuensi pembiayaan mustahik LAZ An-Nuur

\begin{tabular}{ccccc}
\hline Frekuensi pembiayaan (kali) & $\begin{array}{c}\text { Usaha } \\
\text { Berhasil }\end{array}$ & $\begin{array}{c}\text { Usaha Tidak } \\
\text { Berhasil }\end{array}$ & Total & $\begin{array}{c}\text { Persentase } \\
(\%)\end{array}$ \\
\hline 1 & 18 & 7 & 25 & 52.1 \\
2 & 12 & 2 & 14 & 29.2 \\
3 & 7 & 0 & 7 & 14.6 \\
$\geq 4$ & 2 & 0 & 2 & 4.10 \\
\hline
\end{tabular}

Sumber: Data primer, diolah

\section{SIMPULAN DAN SARAN}

\section{Simpulan}

1 Berdasarkan karakteristik responden bagi usahanya yang berhasil mayoritas responden berusia kisaran 31-40 tahun dan 41-50 tahun yang memiliki jumlah yang sama, yaitu berjumlah 13 orang, lama melakukan usaha selama $\geq 7$ tahun sebanyak 15 orang, kemudian memperoleh laba usaha sebesar Rp $1500000 \leq \mathrm{X}<\mathrm{Rp} 2200000$ sebanyak 16 orang, dan telah melakukan pembiayaan sebanyak 1 kali berjumlah 18 orang.

2 Faktor-faktor yang signifikan memengaruhi keberhasilan usaha mustahik dalam mengelola suatu usaha, yaitu usia, lama usaha, laba usaha, dan frekuensi pembiayaan.

\section{Saran}

1 LAZ An-Nuur sebaiknya memberikan pembiayaan kepada responden yang berusia kisaran 31-50 tahun, selain itu sebaiknya memberikan pembiayaan kepada responden yang sudah melakukan usaha selama lebih dari 7 tahun, dan sudah memperoleh laba usaha sebesar Rp1 500000 hingga Rp2 200000.

2 LAZ An-Nuur tidak perlu memberikan pembiayaan kepada responden dengan tingkat pendidikan dan jenis usaha tertentu, karena tingkat pendidikan dan jenis usaha tidak memiliki pengaruh signifikan terhadap keberhasilan usaha.

3 LAZ An-Nuur sebaiknya mengadakan kegiatan pengawasan dan pembinaan kepada mustahik, agar usaha mustahik dapat lebih mudah untuk berhasil. 
4 LAZ An-Nuur perlu memenuhi persyaratan yang tercantum pada UU Nomor 23 Tahun 2011 tentang Pengelolaan Zakat, agar menjadi lembaga yang resmi. Jika tidak memenuhi persyaratan tersebut, LAZ An-Nuur dapat dikenakan tindak pidana.

5 Saran untuk penelitian selanjutnya adalah menambahkan jumlah resonden dan diharapkan dapat menghitung pendapatan sebelum maupun sesudah mendapatkan pembiayaan LAZ An-Nuur. Diharapkan akan ada penelitian mengenai dampak pembiayaan LAZ An-Nuur terhadap perkembangan pendapatan mustahik.

\section{DAFTAR PUSTAKA}

Ali, K.M., Amalia, N.N., \& Ayyubi, S.E. (2016) Perbandingan zakat produktif dan zakat konsumtif dalam meningkatkan kesejahteraan mustahik. Jurnal Al-Muzara'ah, 4(1), 56-67.

Anggraeni, L., Puspitasari, H., Ayyubi, S.E., \& Wiliasih, R. (2013) Akses UMKM terhadap pembiayaan mikro syariah dan dampaknya terhadap perkembangan usaha: Kasus BMT Tadbiirul Ummah, Kabupaten Bogor. Jurnal Al-Muzara'ah, 1(1), 56-67.

Anriani. (2010) BAZ Kota Bogor dan pengentasan kemiskinan. Rubrik Iqtishodia: 29 Juli 2010.

Beik, I.S. (2009) Analisis peran zakat dalam mengurangi kemiskinan: Studi kasus Dompet Dhuafa Republika. Jurnal Pemikiran dan Gagasan, 2.

Beik, I.S. \& Arsyianti, L.D. (2015) Ekonomi Pembangunan Syariah. Bogor, IPB Press.

[BPS] Badan Pusat Statistik. (2017) Gini Ratio Provinsi 2002-2017. [internet]. Tersedia pada: http://www.bps.go.id.

[BPS] Badan Pusat Statistik. (2017) Jumlah Penduduk Miskin Menurut Provinsi, 2007-2017. [internet]. Tersedia pada: http://www.bps.go.id.

[BPS] Badan Pusat Statistik. (2017) Kabupaten Bogor dalam Angka. [internet]. Tersedia pada: https://bogorkab.bps.go.id.

Gina, W. \& Effendi, J. (2015) Program pembiayaan lembaga keuangan mikro syariah (LKMS) dalam peningkatan kesejahteraan pelaku usaha mikro (Studi kasus BMT Baitul Karim Bekasi). Jurnal Al-Muzara'ah, 3(1), 33-43.

Haile. (2015) Determinants of loan repayment performance: Case study of Harari microfinance institutions. Journal of Agricultural Extenction and Rural Development, (7)2, 56-64.

Hartoyo, S. \& Purnamasari, N. (2010) Pengentasan kemiskinan berbasis zakat: studi kasus di Garut. Rubrik Iqtishodia: 29 Juli 2010.

Karimah, S. (2015) Dampak Pembiayaan Qardhul Hasan Terhadap Perkembangan Usaha Mikro (Studi Kasus BMT Al-Husnayain Jakarta). [skripsi]. Bogor, Institut Pertanian Bogor.

[KEMENAG] Kementerian Agama Republik Indonesia. (2011) Undang-Undang Republik Indonesia Nomor 23 tentang Pengelolaan Zakat.

Murniati, R. \& Beik, I.S. (2013) Pengaruh zakat terhadap indeks pembangunan manusia dan tingkat kemiskinan mustahik: Studi kasus pendayagunaan BAZNAS Kota Bogor. Jurnal AlMuzara'ah, 2(2), 135-149.

Mursalina \& Syarifah. (2015) Dampak Pendayagunaan Zakat Produktif terhadap Perkembangan Usaha Mikro Mustahik. Kasus: Usaha Mikro Binaan BAZNAS di Kabupaten Bogor. [skripsi]. Bogor, Institut Pertanian Bogor.

[PUSKAS BAZNAS] Pusat Kajian Strategis Badan Amil Zakat Nasional. (2017) Outlook Zakat Indoneisa 2017. [internet]. Tersedia pada: http://puskasbaznas.com/outlook/indonesia-zakatoutlook-2017.

Rachman. (2014) Dampak Pembiayaan Syariah Terhadap Profitabilitas Usaha Mikro Pada Nasabah Bank Perkreditan Rakyat Syariah Harta Insan Karimah Kecamatan Ciledug Kota Tangerang. [skripsi]. Bogor, Institut Pertanian Bogor.

Rahmi, S. (2012) Analisis Keberlanjutan Finansial dan Faktor-faktor yang Mempengaruhi Pembiayaan Agribisnis pada Koperasi Baytul Ikhtiar Bogor. [skripsi]. Bogor, Institut Pertanian Bogor.

Rozalinda. (2015) Ekonomi Islam:Teori dan Aplikasiya pada Aktivitas Ekonomi. Jakarta, Rajawali Press. 
Tsani, T. (2010) Mengentaskan kemiskinan dan kesenjangan di Lampung Selatan. Rubrik Iqtishodia: 26 Juli 2010.

Tunas, A.N.P. (2014) Analisis Pengaruh Pembiayaan Syariah terhadap Perkembangan Usaha Mikro Kecil Menengah di Kota Depok. [skripsi]. Bogor, Institut Pertanian Bogor.

Widiyanto, Mutamimah, \& Hendar. (2011) Effectiveness of qard al-hasan financing as a poverty alleviation model. Economic Journal of Emerging Markets, 3(1), 27-42. 